\title{
Effect of Growth Factor In Callus Induction and Bioactive Compounds In Seed Explant of Kaffir Lime (Citrus hystrix DC.)
}

\author{
Woro Anindito Sri Tunjung ${ }^{*}$, Vita Fatonah ${ }^{1}$, Ghea Putri Christy ${ }^{1}$, Sugeng Triono ${ }^{2}$, Lisna Hidayati ${ }^{1}$, \\ Dwi Priyanto ${ }^{1}$, Yekti Asih Purwestri ${ }^{1}$, Aries Bagus Sasongko ${ }^{1}$, Hennisa $^{1}$, Nur Faizah ${ }^{1}$ and Ari \\ Indrianto ${ }^{1}$.
}

1. Faculty of Biology Universitas Gadjah Mada, Jalan Teknika Selatan Sekip Utara Yogyakarta 55281 Indonesia.

2. Department of Chemistry, Faculty of Mathematic and Sciences, Universitas Gadjah Mada, Jalan Teknika Selatan Sekip Utara Yogyakarta 55281 Indonesia.

\begin{tabular}{l}
\hline Info Article \\
\hline Submitted: 04-09-2019 \\
Revised: 29-01-2020 \\
Accepted: 05-06-2020 \\
*Corresponding author \\
Woro Anindito Sri Tunjung \\
Email: \\
wanindito@ugm.ac.id
\end{tabular}

\section{INTRODUCTION}

Kaffir lime (Citrus hystrix DC.) is a variety of citrus which is native to Indonesia, Malaysia and Thailand. Kaffir lime is used in food spices, dish flavorings and aroma therapy. According to (Aziman et al., 2012), kaffir lime contains compounds that may be useful medicinally. Our previous study revealed that chloroform and ethyl acetate leaf extracts of kaffir lime have cytotoxic effect on cervical cancer and neuroblastoma cells (Tunjung, et al., 2015). In addition, HutadilokTowatana et al. (2006) showed that extracts of kaffir lime leaves and fruit have antioxidant, antimicrobial, and anti-inflammatory activity.

Production of secondary metabolites are affected by external factors such as biotic and abiotic enviroment. Unfortunately, the content of bioactive compounds in foods with medicinal properties are unstable throughout the year, which may reduce their efficacy. Thus we need biotechnological approach to maintain the quality and potentially increase the quantity of secondary metabolites. The tissue culture can be used to control environmental factors and stabilize secondary metabolite production (Constable, 1984). Callus induction in vitro allows a more consistent and uniform production of natural products. From an economical point of view, tissue culture is very profitable because it allows production of natural products in shorter time and does not need large areas, and in this way it is wellsuited for use in urban environments. 
Table I. Effect of different combination of 2.4-D and BAP on callus induction from kaffir lime seeds explants culture on MS medium

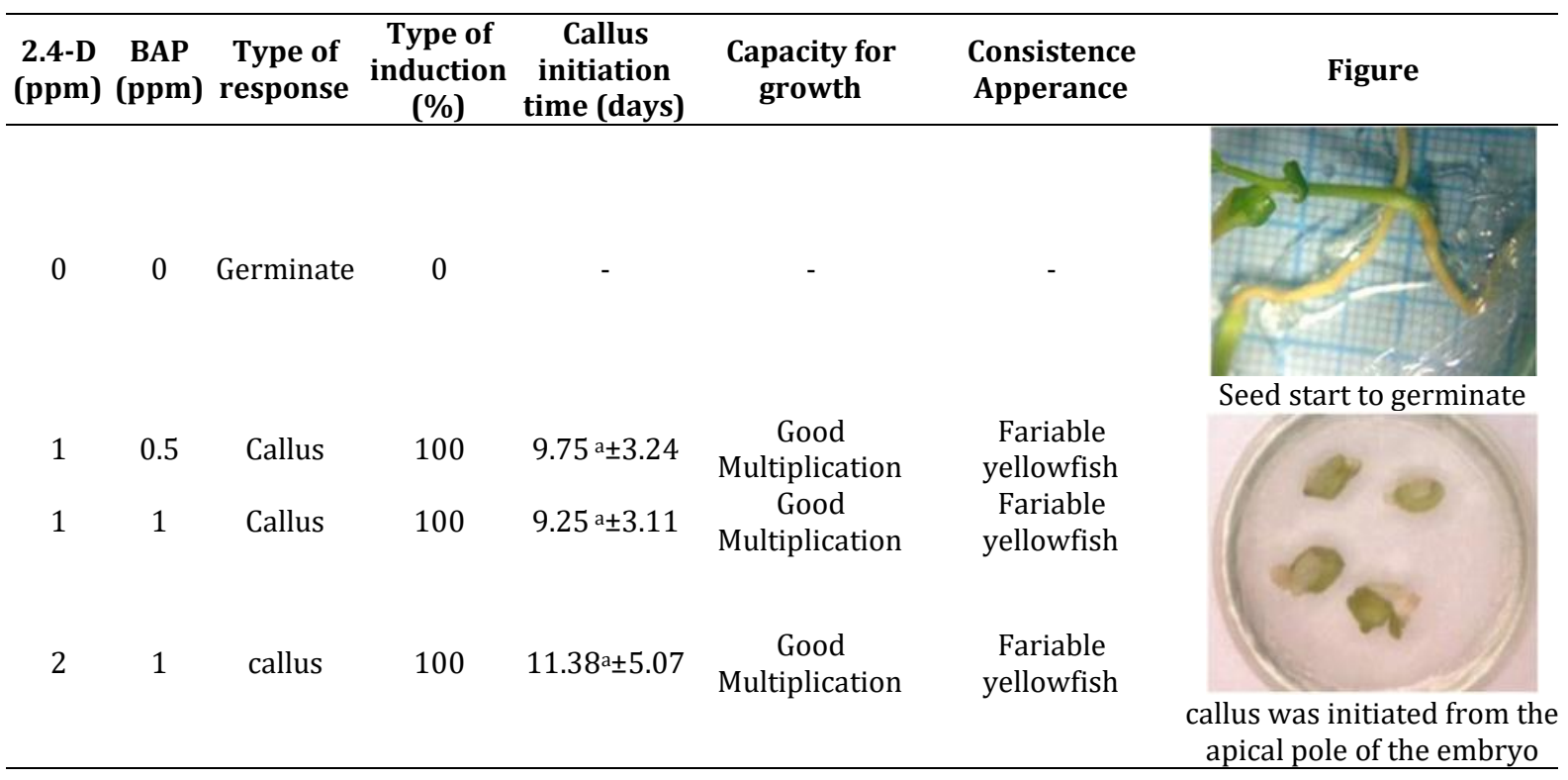

*same letter means there are no significantly different at the 95\% confidence level according to a Duncan's Test

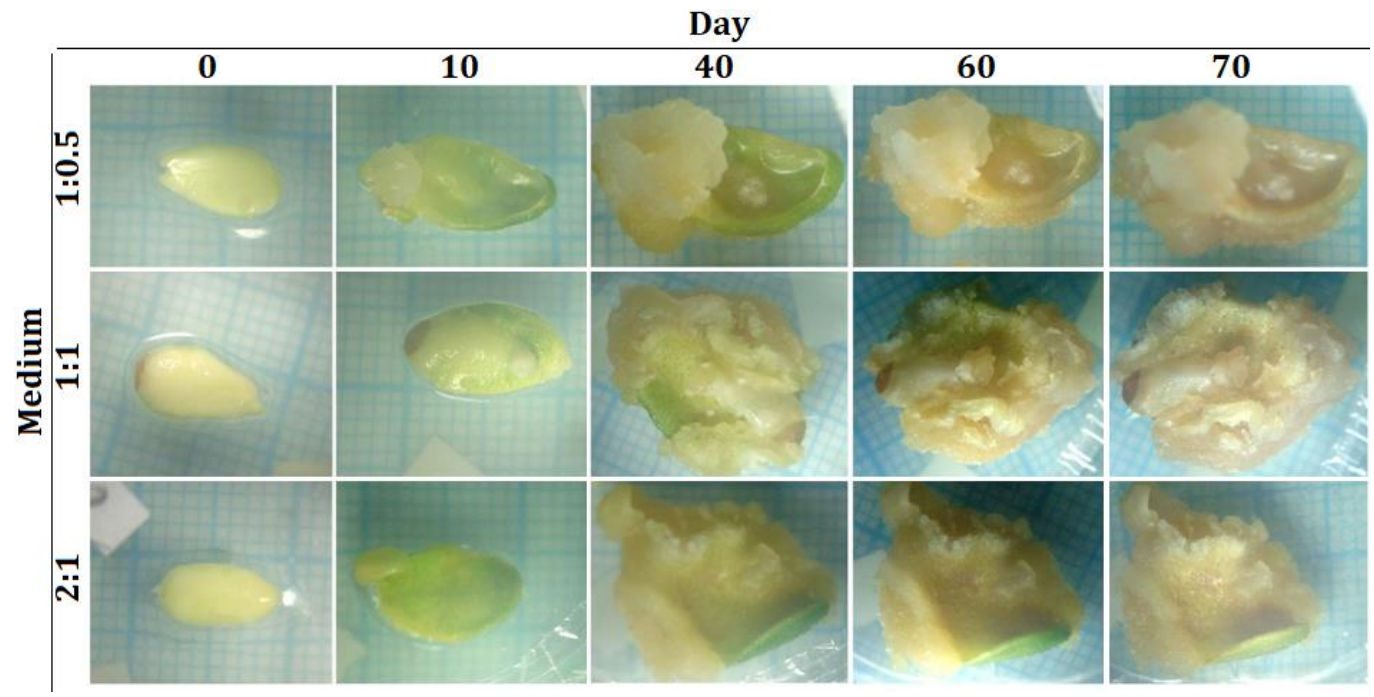

Figure 1. Callus growth and development

Calluses are induced using explants that are inoculated aseptically into a culture medium with addition of various combinations of plant growth regulators. Citrus embryo explants have been shown to be the most responsive to callus induction and proliferation (Jajoo, 2010) thus we used seed explant in this study. Furthermore, a previous study by Ramdan et al. (2014) showed that callus induction using embryos of Citrus rootstocks was succesful after addition of synthetic Auxin 2,4-D (2,4-diclorophenoxy acetic acid) and synthetic Cytokinin BAP (Benzylaminopurine). 2,4-D accelerate cell's proliferation and cell's division whereas BAP plays a role in stimulating cell division. Therefore the objectives of this study were to induce callus formation from kaffir lime seeds in MS medium with combinations of 2,4-D and BAP, and to analyze the profiles of bioactive compounds in kaffir lime callus. 


\section{MATERIAL AND METHODS \\ Collection of kaffir lime fruits}

Fruits were collected from Kaffir lime plantation at Kali Duren, Candirejo, Borobudur Magelang, Central Java, Indonesia.

\section{Sterilization and callus induction of kaffir lime seeds}

Fresh kaffir lime fruits were cut and the seeds then be shelled to discard their outer layer. Seeds were sterilized with $\mathrm{NaClO} 5.25 \%$ (SigmaAldrich) for $5 \mathrm{~min}$ by gently shaking in aseptic condition to protect the seeds from contaminant.. Mature embryos were excised from seeds aseptically and induced on MS (Murashige and Skoog, 1962) standard medium which contained 8g/L agar (Bioagar, Swallow globe) and 30g/L sucrose. The $\mathrm{pH}$ of the medium was adjusted to 5.86.3. Combinations of 2.4D (Merck Millipore) and BAP (Merck Millipore) were applied at relative concentrations of 1:0.5 (ppm); 1:1 (ppm); and 2:1 (ppm) for callus induction. MS0 (without addition of plant growth regulators) was used as control. Culture was incubated at $\pm 25^{\circ} \mathrm{C}$ in dark condition.

\section{Callus growth}

Callus growth was determined by measuring callus initiation time, percentage of callogenesis, callus biomass, and callus morphology. The callus growth curve was obtained from callus biomass and growth was measured every 5 days until 70 days of culture.

\section{Analysis of callus bioactive compounds}

Based on the curve of callus growth, 40 and 60 days-old calluses were chosen to be macerated using chloroform and ethyl acetate. The extracts were then analyzed by GCMS Shimadzu GCMS-QP 2010S, with a non polar column AGILENT HP-5 MS with $95 \%$ dimethyl polysiloxane and $5 \%$ diphenyl polysiloxane to determine the profile of callus bioactive compounds. Gas chromatograph linked to a mass spectrometer available at Organic Chemistry Laboratory, Universitas Gadjah Mada, Yogyakarta, Indonesia.

\section{RESULTS AND DISCUSSION}

Callus was initiated from the apical pole of the embryo. All regions of explants displayed swelling. Medium with all combinations of 2,4-D and BAP $(1: 0.5 ; 1: 1 ; 2: 1)$ can induce calluses from seed explants after 7 days of inoculation. On the contrary, control (MS medium only) was not able to induce callus formation. Furthermore, in the control group seeds germinated after a few days of inoculation. It showed the important role of growth regulators in callus induction. Effects of different combination of 2,4-D and BAP on callus induction from kaffir lime seed explants cultured on MS medium (Table I). All combination's mediums of 2,4-D and BAP were able to induce callus formation. Each treatment required different times to reach $100 \%$ callus formation; however there was no significant difference in callus initiation time (Table I). All calluses have friable texture and typical odor. Callus's texture is one of the markers used to determine the quality of a callus. A friable callus can be used to generate cell suspension cultures. Calluses were yellow, transparent and shiny, and has a typical flavor that is similar to the kaffir lime's leaf. During its development, calluses change their colour to brownish indicating that the callus has entered its death phase. This process indicated decreasing nurients and accumulation of secondary metabolites. Browning was detected on the $50^{\text {th }}$ day. Callus growth and development during 70 days of in vitro callus culture (Figure 1).

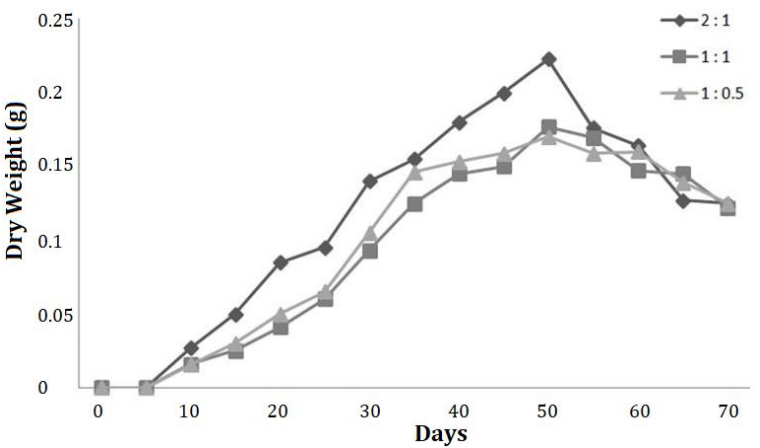

Figure 2. Growth curve of callus of Citrus hystrix DC. During 70 days of culture

The callus dry weight was used to determine the growth curve (Figure 2). The rate of callus growth forms a sigmoid curve. Growth curves from 3 combinations of medium with 2,4-D:BAP showed a similar pattern that presented sigmoidal shape, with 3 phases: lag phase, exponential and stationary phase. The lag phase occurred from the beginning of the culture until the $10^{\text {th }}$ day after inoculation (DAI), during preparation for cell division. The exponential phase is the period of maximum cell division, and formation of a mass of unorganized cells occurred from the $10^{\text {th }}$ DAI to the $50^{\text {th }}$ DAI. The last phase was the stationary phase that started at the $50^{\text {th }}$ DAI. Callus growth was stagnant, where no cell division or weight change occurs and the callus changed colour to brownish. 
At the end of the $60^{\text {th }}$ DAI callus growth began to decline due to nutrient reduction. The in vitro culture was stopped at 70 DAI because the callus had turned brown. Further studies regarding methods to subculture kaffir lime callus are needed.

This study revealed that all combination of 2.4D and BAP were able to induce callogenesis from seed embryo explants of kaffir lime with no significant differences in callus initiation time, biomass and morphology. Callus texture was friable. Callus growth curves were sigmoidal in shape, with three phases, a lag phages (0-10 DAI), exponential phase (10-50 DAI) and stationary phase (50-60 DAI).

Table II. Profil of bioactive compounds of kaffir lime seeds extracted by ethyl acetate and chloroform

\begin{tabular}{ccc}
\hline Peak & Ethyl acetate extract & Chloroform extract \\
\hline 1 & Methyl ester myristic & 2-heptenal (Z and E) \\
& acid & \\
2 & Methyl ester Oleic & E-2-decenal \\
3 & Methyl ester Palmitic & 2,4-decadieal, (E,E) \\
4 & Methyl ester & E-2-undecenal \\
& Linolelaidic & cyclododecene \\
5 & Methyl ester Elaidic \\
6 & Methyl ester 10- \\
7 & octodecanoid \\
7 & Methyl ester Stearic \\
\hline
\end{tabular}

We analyzed bioactive compounds in ethyl acetate and chloroform extracts from seeds and calluses. Thus we can compare bioactive compounds from seeds and calluses derived from seed explants. Bioactive compounds of kaffir lime seeds of each peak (Table II). This result showed that bioactive compounds detected in kaffir lime seeds are mostly derived from fatty acid. The seed is an embryonic plant enclosed with a protective outer covering. Thus, compared to the other part, seeds usually have many primary metabolic compounds necessary for embryo nutrition.

Profiles of callus bioactive compounds were analyzed by GC-MS using 40 and 60 days-old calluses to compare bioactive compounds produced in the exponential and stationary phases (Table III and Table IV). In total from both solvents, chromatograms of 40 days-old calluses showed fewer peaks than 60 days-old callus. In addition, ethyl acetate and chloroform were capable to dissolving secondary metabolites compounds detected on both medium 1:0.5 and 2:1 (Table IV).
Table III. Number of bioactive peak on GC-MS chromatogram

\begin{tabular}{ccccc}
\hline \multirow{2}{*}{$\begin{array}{c}\text { Callus } \\
\text { days-old }\end{array}$} & \multirow{2}{*}{ Solvent } & \multicolumn{3}{c}{$\begin{array}{c}\text { Peaks detected in } \\
\text { medium* }\end{array}$} \\
\cline { 3 - 5 } & & $\mathbf{1 : 0 . 5}$ & $\mathbf{1 : 1}$ & $\mathbf{2 : 1}$ \\
\hline \multirow{2}{*}{40} & Ethyl acetate & 10 & 8 & 7 \\
& Chloroform & 5 & 10 & 5 \\
\multirow{2}{*}{60} & Ethyl acetate & 6 & 7 & 5 \\
& Chloroform & 15 & 25 & 17 \\
\hline
\end{tabular}

Bioactive compounds detected in ethyl acetate and chloroform extract in both 40 and 60 days-old callus in all combinations of 2,4-D and BAP were mostly derived from fatty acids (Table IV). This phenomenon possibly resulted because calluses are still in the growth period and therefore most of the cells synthesize more primary metabolites.

Common and uncommon bioactive compounds in each group. Bioactive compounds that were common to all groups regardless of solvent were fatty acids such as palmitic and oleic acid (Table IV). There was a decrease of these common compounds found in combinations of 2,4D: BAP of 2:1 ppm. This might be due to an increase in the concentration of the $2.4 \mathrm{D}$ in the medium. The different hormone concentrations in medium lead to the alteration of callus bioactive compounds synthesis. On the other hand, both fatty acid and secondary metabolites were detected in callus extracts. Callus induction was able to initiate the formation of secondary metabolites that were detected in a phase-specific manner. In contrast to the seed, the callus is an aggregate of meristematic cells that can differentiate into different types of tissue. Thus, secondary metabolic compounds were synthesized in callus and were more varied than in seeds. The various types of bioactive compounds in calluses were also a result of induction from 2,4-D and BAP in medium.

This study showed that different solvents dissolve different secondary metabolites. Ethyl acetate was capable of dissolving secondary metabolite compounds that were predicted such as $\alpha$-pinene and 1.8-cineole. They were detected only in 40 days-old calluses cultured in medium with combinations of 2,4-D and BAP 1:0.5 and 2:1. On the other hand, chloroform was capable of dissolving different types of secondary metabolites in all treatments of 60 days-old calluses which were not detected in ethyl acetate extracts. 
Table IV. Profile bioactive compounds of 40 and 60 day old calluses extracted by ethyl acetate and chloroform.

\begin{tabular}{|c|c|c|c|c|c|c|c|}
\hline \multirow{3}{*}{$\begin{array}{l}\text { Combination } \\
\text { 2.4D:BAP } \\
\text { (ppm) }\end{array}$} & \multicolumn{3}{|c|}{ Common Bioactive Compounds } & \multicolumn{4}{|c|}{ Different Bioactive Compounds } \\
\hline & \multirow{2}{*}{$\begin{array}{c}40 \& 60 \\
\text { DAI }\end{array}$} & \multirow{2}{*}{$40 \mathrm{DAl}$} & \multirow{2}{*}{$60 \mathrm{DAl}$} & \multicolumn{2}{|c|}{$40 \mathrm{DAl}$} & \multicolumn{2}{|c|}{$60 \mathrm{DAl}$} \\
\hline & & & & Ethyl Acetate & Chloroform & Ethyl Acetate & Chloroform \\
\hline $1: 0.5$ & $\begin{array}{l}\text { Palmitic acid; } \\
\text { Oleic acid }\end{array}$ & $\begin{array}{l}\text { Palmitic } \\
\text { acid; } \\
\text { Dioctyl } \\
\text { adipate }\end{array}$ & $\begin{array}{l}\text { Palmitic acid; } \\
\text { Oleic acid; } \\
\text { Stearic acid; } \\
\text { Dioctyl adipate; } \\
\text { Stigmasterol; } \\
\text { Clionasterol }\end{array}$ & $\begin{array}{l}\text { Alpha-pinene; 1,8- } \\
\text { Cineole; 1,6- } \\
\text { Dioxacyclododecane } \\
\text {-7, 12-dione; Ethyl } \\
\text { oleate; Methyl } \\
\text { palmitate; ethyl } \\
\text { palmitate }\end{array}$ & $\begin{array}{l}\text { Methyl elaidate; } \\
\text { Methyl palmitate; } \\
\text { Ethyl palmitate }\end{array}$ & Cyclodecena & $\begin{array}{l}\text { (Z)-2Decenal; cis-13- } \\
\text { octadecenal; } \\
\text { Cyclohexane eicosyl; } \\
\text { Caryophyllene; } \\
\text { Androstan-17-one, 3- } \\
\text { ethyl-3-hydroxy- } \\
\text { (5.alpha); Palmitin,2- } \\
\text { mono; Linoleolyl } \\
\text { chloride; Cholesta-4,6- } \\
\text { dien-3 ol, benzoate, } \\
\text { (3.beta)-; }\end{array}$ \\
\hline $1: 1$ & $\begin{array}{l}\text { Palmitic acid; } \\
\text { Oleic acid }\end{array}$ & & & $\begin{array}{l}\text { 1,6- } \\
\text { Dioxacyclododecane } \\
-7,12-\text { dione;1- } \\
\text { Phenanthrenecarbox } \\
\text { ylic acid; } \\
\text { 1,2,3,4,4a,9,10,10a- } \\
\text { octahydro-1,4a- } \\
\text { dimethyl-7-(1- } \\
\text { dimethyilethyl)-,R- } \\
\text { (1,alpha, 4a, beta, } \\
\text { 10a.alpha); Stearic } \\
\text { acid }\end{array}$ & $\begin{array}{l}\text { Hexanal; } \\
\text { Isooctane; 2- } \\
\text { Pentatone; 4- } \\
\text { hydroxy-4- } \\
\text { methyl-; (Z)- } \\
\text { 2Decenal; } \\
\text { Evodinnol; Stearic } \\
\text { acid }\end{array}$ & $\begin{array}{l}\text { Seselin; } \\
\text { Stearic acid; } \\
\text { Stearic acid; } \\
\text { Margaric acid }\end{array}$ & $\begin{array}{l}\text { Isododecane; } \\
\text { Hexadecane; Pristane; } \\
\text { Methyl palmitate; } \\
\text { Ethyl palmitate; } \\
\text { Methyl linoleluidate; } \\
\text { Methyl elaidate; } \\
\text { Methyl stearat; 1,3- } \\
\text { Dipalmitin; Oleol; } \\
\text { Cyclohexenale, } \\
\text { eicosyl; } \\
\text { dihydroergosterol; } \\
\text { Margaric acid }\end{array}$ \\
\hline $2: 1$ & Palmitic acid & & & $\begin{array}{l}\text { 2-Pentanone; 4- } \\
\text { hydroxy-4-methyl-; } \\
\text { Alpha-pinene; 1,8- } \\
\text { Cineole; Methyl } \\
\text { palmitate }\end{array}$ & $\begin{array}{l}\text { Methyl elaidate; } \\
\text { Oleic acid; Methyl } \\
\text { palmitate }\end{array}$ & & $\begin{array}{l}\text { Citronellal; neo- } \\
\text { isopulegol; citronellol; } \\
\text { Geraniol; (Z)-2- } \\
\text { Decenal; Eugenol; } \\
\text { Cyclopropane, -1(-2-- } \\
\text { methylene-3-butenyl)- } \\
\text { 1-(1- } \\
\text { methylenepropyl); } \\
\text { Elemol; Nerolidol Z } \\
\text { dan E; Farnesol; } \\
\text { Palmitin, 1,3-di-; } \\
\text { Glyceryl palmitate; } \\
\text { Thiogeraniol }\end{array}$ \\
\hline
\end{tabular}

However calluses with combinations of 2,4-D and BAP 1:0,5 and 2:1 produced more secondary metabolites than combinations of $1: 1$. Both combinations have the same ratio, in which the amount of BAP is half of 2,4-D. This data reveals that the ratio of 2,4-D and BAP have a very important impact to production of bioactive compounds.

This study indicates that production of secondary metabolites in kaffir lime calluses occurs in both exponential and stationary phase. The number and type of secondary metabolites detected in 40 and 60 days-old calluses was different according to the solvent used in extraction. Production of secondary metabolites produced during both exponential and stationary phase is supported by previous studies. According to study in tea cell suspension culture (Muthaiya et al., 2013), production of catechin is higher during the stationary phase rather than in both the lag phase and exponential phase. However based on a review (Shahzad et al., 2013), it has been shown that some plants such as Haplopappus, Rosa, Datura, Scopolia, Andrographis, Morinda and Poppulus were able to produce secondary metabolites in the early exponential phase. The secondary metabolites are anthocyanin formation by Haplopappus and Poppulus cells, phenolic 
production by Rosa cells, tropane alkaloid by Datura and Scopolia, sesquiterpene lactone by Andrographis, anthraquinone by Morinda. These data reveal that different species have different production patterns of bioactive compound.

Many bioactive compounds detected in this study are known to have a medicinal role. Our results warrant the further investigation of kaffir lime callus extracts for a more complete understanding of their potential for therapeutic use. Secondary metabolites detected in callus extract (Table V).

From this study it can be concluded that the combinations of 2.4D and BAP are able to induce callogenesis which yields friable callus. Proportion difference of 2.4 D to BAP has no significant effect on callus initiation time, biomass and morphology. However differences were detected in the bioactive compound profiles. In kaffir lime callus, both fatty acids and secondary metabolites were detected. Specifically, in 40 days-old calluses (exponential growth phase) we detected $\alpha$-pinene and 1,8cineole in plants treated with 2,4-D: BAP at concentration 1:0.5 and 2:1. In 60 days-old calluses (stationary phase) we detected a number of compounds in plants treated with 2,4-D:BAP at concentrations of 1:0.5 and 2:1, including caryophyllene, linoleoyl chloride, thiogeraniol, stigmasterol, clianosterol, citronellal, neoisopulegol, citronellol, geraniol, eugenol, cyclopropane, pristane, elemol and farnesol.

\section{CONCLUSION}

All combinations of 2,4-D and BAP were able to induce callogenesis from seed embryo explants of kaffir lime with no significant differences of callus initiation time, biomass, morphology and growth rates. However differences were detected in the bioactive compound profiles. Those secondary metabolites detected in callus are known for their anti-cancer, anti-oxidant, antiinflammatory, anti-fungal, antibacterial properties etc. This finding suggests that kaffir lime callus might be potential resource for large-scale industrial production of secondary metabolites, which is valuable in pharmaceutical industry.

\section{ACKNOWLEDGMENTS}

This work was financially supported by Penelitian Unggulan Perguruan Tinggi 2016 and Penelitian Dasar Unggulan Perguruan Tinggi 2018 from Ministry of Research, Technology and Higher education (to W.A.S.T).

\section{REFERENCES}

Assis, L. C., Straliotto, M. R., Engel, D., Hort, M. A., Dutra, R. C., \& de Bem, A. F. (2014). $\beta$ Caryophyllene protects the C6 glioma cells against glutamate-induced excitotoxicity through the Nrf2 pathway. Neuroscience, 279, 220-231. https://doi.org/10.1016/j.neuroscience.20 14.08.043

Aziman, N., Abdullah, N., Mohd Noor, Z., Zulkifli, K. S., \& Wan Kamarudin, W. S. S. (2012). Phytochemical constituents and in vitro bioactivity of ethanolic aromatic herb extracts. Sains Malaysiana, 41(11), 14371444.

Batta, A. K., Xu, G., Honda, A., Miyazaki, T., \& Salen, G. (2006). Stigmasterol reduces plasma cholesterol levels and inhibits hepatic synthesis and intestinal absorption in the rat. Metabolism: Clinical and Experimental, 55(3),

292-299. https://doi.org/10.1016/j.metabol.2005.08 .024

Brito, R. G., Dos Santos, P. L., Quintans, J. S. S., De Lucca Júnior, W., Araújo, A. A. S., Saravanan, S., ... Quintans-Júnior, L. J. (2015). Citronellol, a natural acyclic monoterpene, attenuates mechanical hyperalgesia response in mice: Evidence of the spinal cord lamina $\mathrm{i}$ inhibition. Chemico-Biological Interactions, 239, 111-117. https://doi.org/10.1016/j.cbi.2015.06.039

Chavan, M. J., Wakte, P. S., \& Shinde, D. B. (2010). Analgesic and anti-inflammatory activity of Caryophyllene oxide from Annona squamosa L. bark. Phytomedicine, 17(2), 149-151.

https://doi.org/10.1016/j.phymed.2009.05 .016

Chen, W., Liu, Y., Li, M., Mao, J., Zhang, L., Huang, R., ... Ye, L. (2015). Anti-tumor effect of $\alpha$ pinene on human hepatoma cell lines through inducing G2/M cell cycle arrest. Journal of Pharmacological Sciences, 127(3), 332-338.

https://doi.org/10.1016/j.jphs.2015.01.00 8

Daudin, J. B., Monnet, D., Kavian, N., Espy, C., Wang, A., Chéreau, C., ... Nicco, C. (2011). Protective effect of pristane on experimental autoimmune uveitis. Immunology Letters, 141(1), 83-93. https://doi.org/10.1016/j.imlet.2011.07.00 9 
Hutadilok-Towatana, N., Chaiyamutti, P., Panthong, K., Mahabusarakam, W., \& Rukachaisirikul, V. (2006). Antioxidative and free radical scavenging activities of some plants used in Thai folk medicine. Pharmaceutical Biology, 44(3), 221-228. https://doi.org/10.1080/13880200600685 592

Jajoo, A. (2010). In vitro propagation of Citrus limonia Osbeck through nucellar embryo culture. Curr. Res. J. Bio. Sci, 2(1), 6-8. Retrieved from http://www.maxwellsci.com/print/crjbs/v 2-6-8.pdf

Joo, J. H., Ueda, E., Bortner, C. D., Yang, X. P., Liao, G., \& Jetten, A. M. (2015). Farnesol activates the intrinsic pathway of apoptosis and the ATF4-ATF3-CHOP cascade of ER stress in human $\mathrm{T}$ lymphoblastic leukemia Molt4 cells. Biochemical Pharmacology, 97(3), 256268.

https://doi.org/10.1016/j.bcp.2015.08.086

Júnior, P. L. de S., Câmara, D. A. D., Costa, A. S., Ruiz, J. L. M., Levy, D., Azevedo, R. A., ... Ferreira, A. K. (2016). Apoptotic effect of eugenol envolves G2/M phase abrogation accompanied by mitochondrial damage and clastogenic effect on cancer cell in vitro. Phytomedicine, 23(7), 725-735. https://doi.org/10.1016/J.PHYMED.2016.0 3.014

Khan, R., \& Sultana, S. (2011). Farnesol attenuates 1,2-dimethylhydrazine induced oxidative stress, inflammation and apoptotic responses in the colon of Wistar rats. Chemico-Biological Interactions, 192(3), 193-200.

https://doi.org/10.1016/j.cbi.2011.03.009

Laboratory Procedures and Their Applications Google Books. (n.d.). Retrieved October 30, 2019,

from https://books.google.co.id/books?hl=en\&lr $=\& \mathrm{id}=\mathrm{cSyJF7PyADYC} \& \mathrm{oi}=\mathrm{fnd} \& \mathrm{pg}=\mathrm{PA} 27 \& \mathrm{dq}$ $=$ Callus+culture:+Induction+and+maintena nce\&ots=RLMjXvf5Ui\&sig=onTuFRgdbvCjtY _3HtQfWRhwRhM\&redir_esc=y\#v=onepage $\& q=$ Callus culture $\% 3 \mathrm{~A}$ Induction and maintenance\&f $=$ false

Lee, Jong Hyun, Kim, C., Kim, S. H., Sethi, G., \& Ahn, K. S. (2015). Farnesol inhibits tumor growth and enhances the anticancer effects of bortezomib in multiple myeloma xenograft mouse model through the modulation of STAT3 signaling pathway. Cancer Letters,
$360(2)$,

280-293. https://doi.org/10.1016/j.canlet.2015.02.0 24

Lee, Jung Hwan, Lee, H. H., Kim, K. N., \& Kim, K. M. (2016). Cytotoxicity and anti-inflammatory effects of zinc ions and eugenol during setting of ZOE in immortalized human oral keratinocytes grown as three-dimensional spheroids. Dental Materials, 32(5), e93e104.

https://doi.org/10.1016/j.dental.2016.01.0 03

Maßberg, D., Simon, A., Häussinger, D., Keitel, V., Gisselmann, G., Conrad, H., \& Hatt, H. (2015). Monoterpene (-)-citronellal affects hepatocarcinoma cell signaling via an olfactory receptor. Archives of Biochemistry and Biophysics, 566, 100-109. https://doi.org/10.1016/J.ABB.2014.12.00 4

Matsuo, A. L., Figueiredo, C. R., Arruda, D. C., Pereira, F. V, Scutti, J. A. B., Massaoka, M. H., ... Lago, J. H. G. (2011). $\alpha$-Pinene isolated from Schinus terebinthifolius Raddi (Anacardiaceae) induces apoptosis and confers antimetastatic protection in a melanoma model. Biochemical and Biophysical Research Communications, 411(2), 449-454. https://doi.org/10.1016/j.bbrc.2011.06.17 6

Muthaiya, M. J., Nagella, P., Thiruvengadam, M., \& Mandal, A. A. (2013). Enhancement of the productivity of tea (Camellia sinensis) secondary metabolites in cell suspension cultures using pathway inducers. Journal of Crop Science and Biotechnology, 16(2), 143149. https://doi.org/10.1007/s12892-0120124-9

Panda, S., Jafri, M., Kar, A., \& Meheta, B. K. (2009). Thyroid inhibit1. Panda S, Jafri M, Kar A, Meheta BK. Thyroid inhibitory, antiperoxidative and hypoglycemic effects of stigmasterol isolated from Butea monosperma. Fitoterapia [Internet]. 2009 [cited 2017 Dec 25];80(2):123-6. Available from: http://www.nc. Fitoterapia, 80(2), 123-126.

https://doi.org/10.1016/j.fitote.2008.12.00 2

Park, K.-R., Nam, D., Yun, H.-M., Lee, S.-G., Jang, H.-J., Sethi, G., ... Ahn, K. S. (2011). $\beta$ Caryophyllene oxide inhibits growth and induces apoptosis through the suppression of $\mathrm{PI} 3 \mathrm{~K} / \mathrm{AKT} / \mathrm{mTOR} / \mathrm{S} 6 \mathrm{~K} 1$ pathways and 
ROS-mediated MAPKs activation. Cancer Letters, 312(2), 178-188. https://doi.org/10.1016/j.canlet.2011.08.0 01

Patel, S., \& Gogna, P. (2015, December 15). Tapping botanicals for essential oils: Progress and hurdles in cancer mitigation. Industrial Crops and Products, Vol. 76, pp. 1148-1163. https://doi.org/10.1016/j.indcrop.2015.08. 024

Prasad, S. N., \& Muralidhara. (2014). Neuroprotective effect of geraniol and curcumin in an acrylamide model of neurotoxicity in Drosophila melanogaster: Relevance to neuropathy. Journal of Insect Physiology, 60(1), 7-16. https://doi.org/10.1016/j.jinsphys.2013.10 .003

Ramdan, ), Handaji N, Beyahia H, \& Ibriz M 1. (n.d.). Influence of growth regulators on callus induction from embryos of five citrus rootstocks. Retrieved from www.m.elewa.org

Santhanasabapathy, R., Vasudevan, S., Anupriya, K., Pabitha, R., \& Sudhandiran, G. (2015). Farnesol quells oxidative stress, reactive gliosis and inflammation during acrylamideinduced neurotoxicity: Behavioral and biochemical evidence. Neuroscience, 308, 212-227.

https://doi.org/10.1016/J.NEUROSCIENCE. 2015.08.067

Shahzad, A., Shaheen, A., Kozgar, M. I., Sahai, A., \& Sharma, S. (2013). Phytoactive Compounds from In Vitro Derived Tissues. In Recent Trends in Biotechnology and Therapeutic Applications of Medicinal Plants (pp. 1-23). https://doi.org/10.1007/978-94-0076603-7_1

Siddique, Y. H., Naz, F., Jyoti, S., Ali, F., Fatima, A., Rahul, \& Khanam, S. (2016). Protective effect of Geraniol on the transgenic Drosophila model of Parkinson's disease. Environmental Toxicology and Pharmacology, 43, 225-231. https://doi.org/10.1016/J.ETAP.2016.03.0 18

Silva, M. I. G., Silva, M. A. G., de Aquino Neto, M. R., Moura, B. A., de Sousa, H. L., de Lavor, E. P. H., ... de Sousa, F. C. F. (2009). Effects of isopulegol on pentylenetetrazol-induced convulsions in mice: Possible involvement of GABAergic system and antioxidant activity.
Fitoterapia, $\quad$ 80(8), 506-513. https://doi.org/10.1016/j.fitote.2009.06.01 1

Srinivasan, S., \& Muruganathan, U. (2016). Antidiabetic efficacy of citronellol, a citrus monoterpene by ameliorating the hepatic key enzymes of carbohydrate metabolism in streptozotocin-induced diabetic rats. Chemico-Biological Interactions, 250, 38-46. https://doi.org/10.1016/j.cbi.2016.02.020

Tunjung, W. A. S., Cinatl, J., Michaelis, M., \& Smales, C. M. (2015). Anti-Cancer Effect of Kaffir Lime (Citrus Hystrix DC) Leaf Extract in Cervical Cancer and Neuroblastoma Cell Lines. Procedia Chemistry, 14, 465-468. https://doi.org/10.1016/j.proche.2015.03. 062

Venkadeswaran, K., Thomas, P. A., \& Geraldine, P. (2016). An experimental evaluation of the anti-atherogenic potential of the plant, Piper betle, and its active constitutent, eugenol, in rats fed an atherogenic diet. Biomedicine \& Pharmacotherapy $=$ Biomedecine \& Pharmacotherapie, 80, 276-288. https://doi.org/10.1016/j.biopha.2016.03. 028

Wang, X., Zhao, S., Su, M., Sun, L., Zhang, S., Wang, D., ... Li, Y. (2016). Geraniol improves endothelial function by inhibiting NOX-2 derived oxidative stress in high fat diet fed mice. Biochemical and Biophysical Research Communications, 474(1), 182-187. https://doi.org/10.1016/j.bbrc.2016.04.09 7

Xie, Y., Yang, Z., Cao, D., Rong, F., Ding, H., \& Zhang, D. (2015). Antitermitic and antifungal activities of eugenol and its congeners from the flower buds of Syzgium aromaticum (clove). Industrial Crops and Products, 77, 780-786. https://doi.org/10.1016/J.INDCROP.2015.0 9.044

Zabka, M., Pavela, R., \& Prokinova, E. (2014). Antifungal activity and chemical composition of twenty essential oils against significant indoor and outdoor toxigenic and aeroallergenic fungi. Chemosphere, 112, 443-448. https://doi.org/10.1016/J.CHEMOSPHERE. 2014.05.014 